\title{
COVID-19 and Posterior Reversible Encephalopathy Syndrome
}

Fabio Noro, MD, PhD, Fernando de Mendonça Cardoso, MD, PhD, and Edson Marchiori, MD, PhD

Neurology: Clinical Practice April 2021 vol. 11 no. 2 e202-e204 doi:10.1212/CPJ.0000000000000904
Correspondence

Dr. Noro

fncursos@gmail.com

The novel severe acute respiratory syndrome coronavirus 2 (SARS-CoV-2) caused an epidemic in December 2019 in Wuhan, China, which became a pandemic (as designated by the WHO), creating a current health emergency. ${ }^{1}$ A preliminary report warned that SARS-CoV-2 had neuroinvasive potential because some infected patients had neurologic symptoms such as headache, nausea, and vomiting. ${ }^{2}$ Several subsequent reports have described the emergence of various neurologic disorders in the evolution of SARS-CoV-2 infectious processes. In this article, we report the case of a patient with coronavirus disease 2019 (COVID-19) who presented with posterior reversible encephalopathy syndrome (PRES), diagnosed on clinical, laboratory, and imaging bases.

\section{Case}

MORE ONLINE

A 67-year-old female patient underwent emergent left carotid endarterectomy due to sudden obstruction of the artery treated previously with stenting and angioplasty. The surgery was successful. In the postoperative period, however, the patient required 10 seconds assisted cardiopulmonary resuscitation, with reversal without any medical or neurologic sequelae. CT of the brain (figure, A) and CT angiography of the brain and neck showed no change and confirmed the patency of the operated artery. After this complication, the patient had a favorable evolution and was discharged 2 days later, asymptomatic.

Four days after discharge, family members found the patient at home with tonic-clonic seizure and loss of consciousness. On admission, she was disoriented and agitated, had difficulty following verbal commands, and mobilizing the extremities, and the pupils were equal, round, and reactive. Her blood pressure was $150 / 88 \mathrm{~mm} \mathrm{Hg}$ (similar to baseline), respiratory rate was 24 breaths/min, and oxygen saturation level $\left(\mathrm{SaO}_{2}\right)$ was $83 \%$. Pulmonary auscultation revealed diffuse bronchi.

Brain CT on admission showed areas of bilateral parieto-occipital hypodensity, suggestive of PRES, with no sign of hemorrhage (figure, $\mathrm{B}$ and C). Owing to the patient's low $\mathrm{SaO}_{2}$ and in the context of the COVID-19 pandemic, chest CT was performed and showed ground-glass opacities in both lungs (figure, D). A nasal-swab RT-PCR test was positive for SARS-CoV-2. The laboratory findings demonstrated leukopenia. The basic metabolic panel, hepatic enzymes, and CSF analysis were without abnormalities.

The patient evolved with full neurologic recovery, but her pulmonary and inflammatory conditions worsened, and she died 1 week later. 


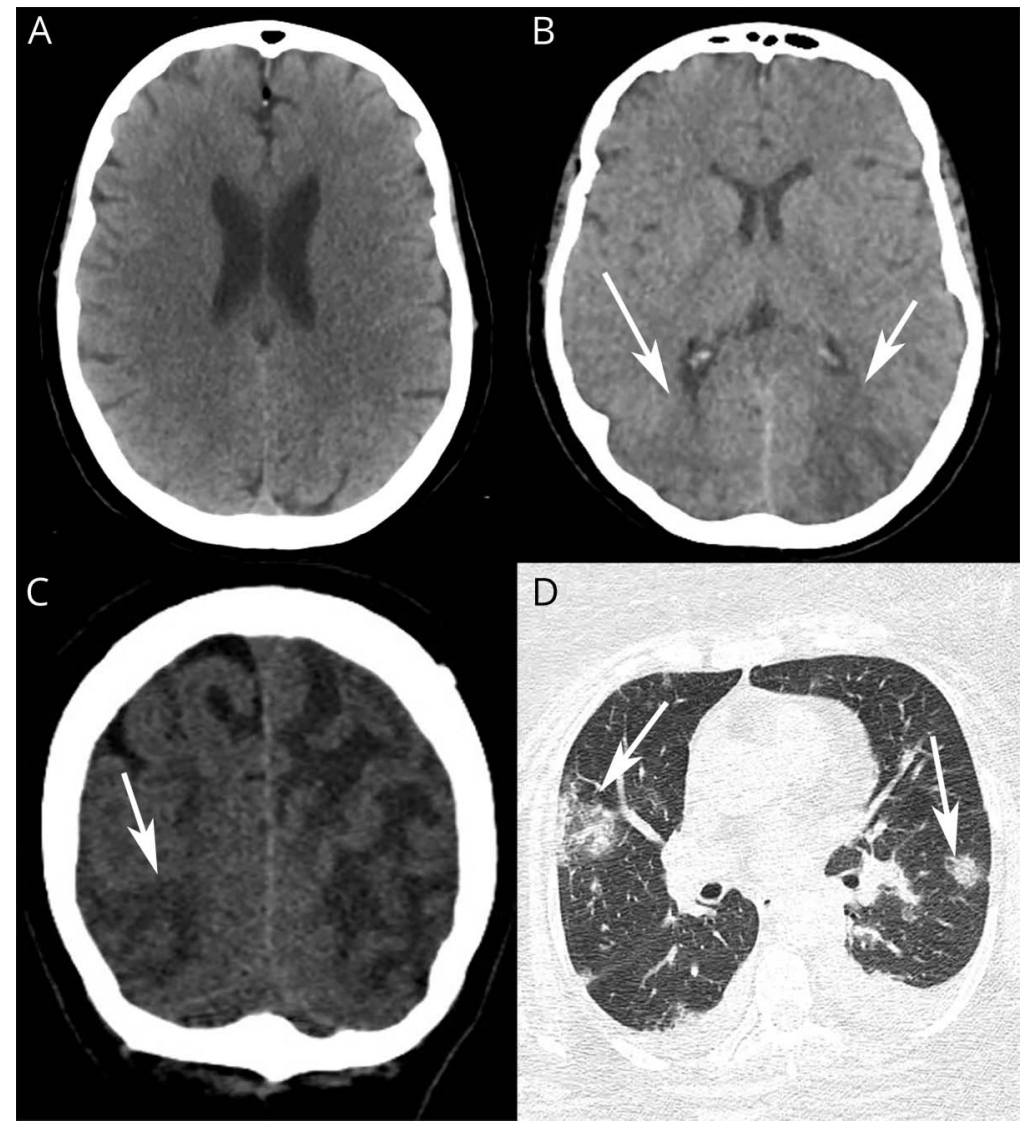

(A) Brain CT performed 7 days before admission showed no abnormality. It was performed after a postsurgical cardiopulmonary resuscitation (promptly reversed and with full recovery). The purpose is to show previously normal parietooccipital regions. (B, C) Brain CT performed on readmission showed bilateral asymmetrical parieto-occipital hypodense lesions (arrows). (D) Chest CT showed round peripheral ground-glass opacities in both lungs (arrows), consistent with findings typically reported in COVID-19 pneumonitis.

\section{Discussion}

Based on clinical, laboratory, and imaging findings, the diagnosis of PRES was proposed, mainly because of the full neurologic recovery and CSF normal, excluding meningoencephalitis and ischemic stroke, the 2 most common conditions.

PRES is characterized by acute onset of neurologic symptoms, vasogenic edema on neuroimaging (hypodense lesions on CT, especially in the parieto-occipital white matter, and hyperintense regions on $\mathrm{T} 2$ and fluid-attenuated inversion recovery MRI), and reversibility of clinical and/or radiologic findings., It is associated mainly with abrupt and severe hypertension, which occurs in eclampsia and acute renal failure. It also occurs in patients treated with immunosuppressive or cytotoxic agents (e.g., cyclosporine and tacrolimus), ${ }^{3}$ those with connective tissue diseases (e.g., systemic lupus erythematosus), ${ }^{5}$ and those with conditions such as thrombotic thrombocytopenic purpura. ${ }^{3}$ Some cases of PRES occur in the absence of hypertension because the pathogenesis of this syndrome is multifactorial. ${ }^{3-6}$ The primary mechanism is the loss of cerebral vascular endothelial cell regulation.
PRES has been associated with an inflammatory state and hypercoagulability, such as in sepsis of various origins. ${ }^{7}$ In the case reported here, the patient was infected with SARS-CoV-2 and presented with a condition compatible with PRES, in clinical and imaging terms, with no other evident justification for the syndrome in her clinical history. Health care providers should be aware that patients with COVID-19 can present with acute neurologic symptoms, and PRES should be considered as a possibility.

\section{Study Funding}

No targeted funding reported.

\section{Disclosure}

F. Noro, F. de Mendonça Cardoso, and E. Marchiori report no disclosures. Full disclosure form information provided by the authors is available with the full text of this article at Neurology.org/cp.

\section{Publication History}

Received by Neurology: Clinical Practice May 23, 2020. Accepted in final form June 23, 2020. 
Appendix Authors

\begin{tabular}{lll}
\hline Name & Location & Contribution \\
\hline $\begin{array}{l}\text { Fabio Noro, MD, } \\
\text { PhD }\end{array}$ & $\begin{array}{l}\text { Federal } \\
\text { University of } \\
\text { Rio de Janeiro }\end{array}$ & $\begin{array}{l}\text { Conception and design of the } \\
\text { study, analysis, and } \\
\text { interpretation of data, } \\
\text { acquisition of data, drafting the } \\
\text { article, and final approval of the } \\
\text { version to be submitted }\end{array}$ \\
\hline $\begin{array}{l}\text { Fernando de } \\
\begin{array}{l}\text { Mendonça } \\
\text { Cardoso, MD, PhD }\end{array}\end{array}$ & $\begin{array}{l}\text { Rede Dor-São } \\
\text { Luiz, Rio de }\end{array}$ & $\begin{array}{l}\text { Analysis and interpretation of } \\
\text { data }\end{array}$ \\
$\begin{array}{l}\text { Edson Marchiori, } \\
\text { MD, PhD }\end{array}$ & $\begin{array}{l}\text { Federal } \\
\text { University of } \\
\text { Rio de Janeiro }\end{array}$ & $\begin{array}{l}\text { Conception and design of the } \\
\text { study and final approval of the } \\
\text { version to be submitted }\end{array}$ \\
\hline
\end{tabular}

\section{References}

1. Wang D, Hu B, Hu C, et al. Clinical characteristics of 138 hospitalized patients with 2019 novel coronavirus-infected pneumonia in Wuhan, China. JAMA 2020;323: 1061-1069.

2. Li YC, Bai WZ, Hashikawa T. The neuroinvasive potential of SARS-CoV2 may be at least partially responsible for the respiratory failure of COVID-19 patients. J Med Virol 2020;92:552-555.

3. Hinchey J, Chaves C, Appignani B, et al. A reversible posterior leukoencephalopathy syndrome. N Engl J Med 1996; 334:494-500.

4. Fischer M, Schmutzhard E. Posterior reversible encephalopathy syndrome. J Neurol 2017;264:1608-1616.

5. Yong PF, Hamour SM, Burns A. Reversible posterior leukoencephalopathy in a patient with systemic sclerosis/systemic lupus erythematosus overlap syndrome. Nephrol Dial Transpl 2003;18:2660-2662.

6. Bakshi R, Shaikh ZA, Bates VE, Kinkel PR. Thrombotic thrombocytopenic purpura: brain CT and MRI findings in 12 patients. Neurology 1999;52: 1285-1288.

7. Yano Y, Kario K, Fukunaga T, et al. A case of reversible posterior leukoencephalopathy syndrome caused by transient hypercoagulable state induced by infection. Hypertens Res 2005;28:619-623. 


\title{
Neurology ${ }^{\circ}$ Clinical Practice
}

\author{
COVID-19 and Posterior Reversible Encephalopathy Syndrome \\ Fabio Noro, Fernando de Mendonça Cardoso and Edson Marchiori \\ Neurol Clin Pract 2021;11;e202-e204 Published Online before print July 8, 2020 \\ DOI 10.1212/CPJ.0000000000000904
}

This information is current as of July 8, 2020

\begin{abstract}
Updated Information \& Services

References

Subspecialty Collections

Permissions \& Licensing

Reprints

including high resolution figures, can be found at:

http://cp.neurology.org/content/11/2/e202.full.html

This article cites 7 articles, 1 of which you can access for free at: http://cp.neurology.org/content/11/2/e202.full.html\#\#ref-list-1

This article, along with others on similar topics, appears in the following collection(s):

COVID-19

http://cp.neurology.org//cgi/collection/covid_19

\section{CT}

http://cp.neurology.org//cgi/collection/ct

Generalized seizures

http://cp.neurology.org//cgi/collection/generalized_seizures

Other cerebrovascular disease/ Stroke

http://cp.neurology.org//cgi/collection/other_cerebrovascular_disease_ _stroke

Viral infections

http://cp.neurology.org//cgi/collection/viral_infections

Information about reproducing this article in parts (figures,tables) or in its entirety can be found online at:

http://cp.neurology.org/misc/about.xhtml\#permissions

Information about ordering reprints can be found online: http://cp.neurology.org/misc/addir.xhtml\#reprintsus
\end{abstract}

Neurol Clin Pract is an official journal of the American Academy of Neurology. Published continuously since 2011, it is now a bimonthly with 6 issues per year. Copyright ( 2020 American Academy of Neurology. All rights reserved. Print ISSN: 2163-0402. Online ISSN: 2163-0933.

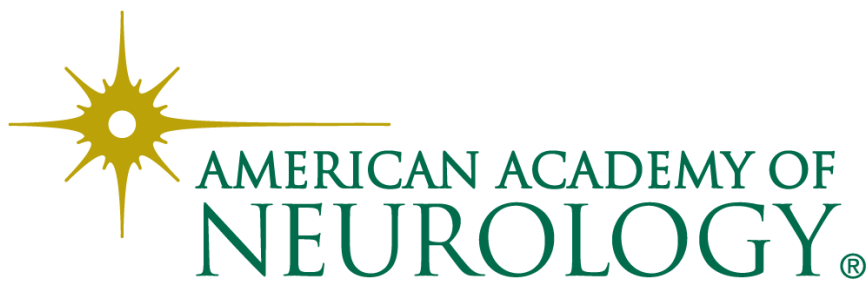

